\title{
PENINGKATAN PARTISIPASI RUKUN TETANGGA DALAM PENGAWASAN PILKADA DAN MEWUJUDKAN PILKADA ANTIPOLITIK UANG
}

\author{
Tatang Sudrajat \\ Program Studi Administrasi Bisnis Universitas Sangga Buana \\ korespondensi : id.tatangsudrajat@gmail.com
}

\begin{abstract}
ABSTRAK
Politik uang dalam penyelenggaraan pilkada merupakan salah satu permasalahan yang terus muncul. Pengawasan pilkada yang dilakukan oleh Bawaslu dan jajarannya sangat penting, tetapi memerlukan adanya partisipasi masyarakat secara efektif. Gerakan masyarakat antipolitik uang merupakan sesuatu yang harus ditumbuhkan untuk berjalannya pilkada yang berkualitas. Dengan metode ceramah, diskusi interaktif dan bedah kasus, tampak bahwa pengurus Rukun Tetangga memiliki perhatian dan antisiasme yang tinggi untuk hadirnya pilkada yang bersih dan terbebas dari politik uang. Bawaslu perlu secara berkesinambungan menumbuhkan dan mengembangkan gerakan masyarakat antipolitik uang sehingga menjadi kekuatan efektif untuk penyelenggaraan pilkada yang berkualitas.
\end{abstract}

Kata Kunci: pengawasan, pilkada, partisipasi.

\begin{abstract}
Money politics in organizing local elections is one of the problems that continues to arise. Local election oversight by Bawaslu and its staff is very important, but requires effective public participation. The moneyanti-political movement of society is something that must be nurtured for quality local elections. With the lecture method, interactive discussions and case reviews, it appears that the Rukun Tetangga administrators have high concern and enthusiasm for the presence of a clean election free from money politics. Bawaslu needs to continuously grow and develop an anti-money political society movement so that it becomes an effective force for the implementation of quality local elections.
\end{abstract}

Keywords: supervision, local election, participation.

\section{PENDAHULUAN}

Dalam negara demokrasi, sirkulasi kepemimpinan secara regular, damai dan berkualitas merupakan suatu keniscayaan. Di Indonesia, Pemilihan Kepala Daerah dan Wakil Kepala Daerah (Pilkada) yang secara langsung oleh rakyat untuk pertama kali diselenggarakan tahun 2005 merupakan bagian penting dari upaya meningkatkan kualitas kehidupan politik dan demokrasi di tingkat lokal. Berdasarkan pengalaman beberapa kali pilkada di berbagai daerah di Indonesia, tampak bahwa berbagai kendala, tantangan dan permasalahan selalu menghadang pada setiap tahap penyelenggaraannya. Salah satu permasalahan yang muncul sehingga menjadi bagian dari dinamika penyelenggaraan pilkada adalah masih maraknya politik uang.

Penyelenggaraan pilkada dalam konteks pembangunan politik, pada dasarnya adalah untuk terlahirnya kapabilitas pemerintahan daerah yang antara lain didukung oleh figur pimpinan daerah yang berintegritas. Terbitnya berbagai kebijakan negara dalam bentuk undang-undang yang mengatur tentang pemilu dan pilkada pada hakekatnya merupakan 
kebijakan publik. Dikatakan demikian, karena substansi yang diatur dalam undang-undang tersebut mengandung muatan kepentingan publik berupa aspirasi dan harapan warga negara di tingkat lokal untuk terpilihnya pimpinan daerah sesuai dengan yang mereka harapkan. Wujud nyata kepentingan publik lainnya adalah harapan untuk hadirnya pilkada yang bersih dan terbebas dari politik uang.

Kebermanfaatan suatu produk kebijakan publik bagi masyarakat pada umumnya akan tampak ketika diimplementasikan. Ini diawali ketika berbagai regulasi tentang pengawasan dalam rangka pecegahan politik uang serta ketentuan pidananya secara eksplisit didiseminasikan oleh penyelenggara pilkada kepada para pemangku kepentingan. Dalam kaitan ini, peran serta unsur masyarakat untuk tegaknya berbagai ketentuan pilkada, khususnya dalam upaya memberantas politik uang menjadi sesuatu yang penting dan strategis bagi terwujudnya tatanan demokrasi yang lebih substantif.

Sebagai bagian integral dari dinamika berbangsa, perguruan tinggi tentu memiliki peran dan tanggung jawab dalam memberikan solusi terhadap permasalahan yang dihadapi masyarakat. Salah satu fungsi perguruan tinggi sebagaimana disebutkan dalam Pasal 4 huruf $b$ Undang-Undang Nomor 12 Tahun 2012 tentang Pendidikan Tinggi adalah mengembangkan sivitas akademika yang inovatif, responsif, kreatif, terampil, berdaya saing dan kooperatif melalui pelaksanaan Tridharma [1]. Salah satu tujuannya sebagaimana disebut dalam Pasal 5 huruf $d$ adalah terwujudnya pengabdian kepada masyarakat berbasis penalaran dan karya penelitian yang bermanfaat dalam memajukan kesejahteraan umum dan mencerdaskan kehidupan bangsa.

Dalam kaitan ini, keterlibatan dosen sebagai unsur sivitas akademika Universitas Sangga Buana YPKP untuk memberikan pemahaman yang komprehensif tentang pentingnya partisipasi warga masyarakat dalam pengawasan pilkada serta untuk mewujudkan pilkada yang antipolitik uang, merupakan wujud nyata kontribusinya bagi perkembangan pembangunan politik di daerah.

\section{METODE}

Prosedur kegiatan diawali oleh adanya surat kepada Drs. Tatang Sudrajat,SIP.M.Si. dari Ketua Badan Pengawas Pemilihan Umum (Bawaslu) Kabupaten Bandung Nomor 021/K.BAWASLU.JB.-01/PM.00.02/III/2020 tanggal 11 Maret 2020 tentang Permohonan Sebagai Narasumber. Selanjutnya Dekan FISIP USB YPKP menerbitkan Surat Tugas Nomor ST-10/FISIP/III/2020 tanggal 11 Maret 2020 kepada Drs. Tatang Sudrajat, SIP.M.Si. untuk menjadi narasumber dalam kegiatan "Sosialisasi Pengawasan Partisipatif dan Pembentukan Rukun Tetangga Antipolitik Uang Pada Pemilihan Bupati dan Wakil Bupati Bandung Tahun 2020". 


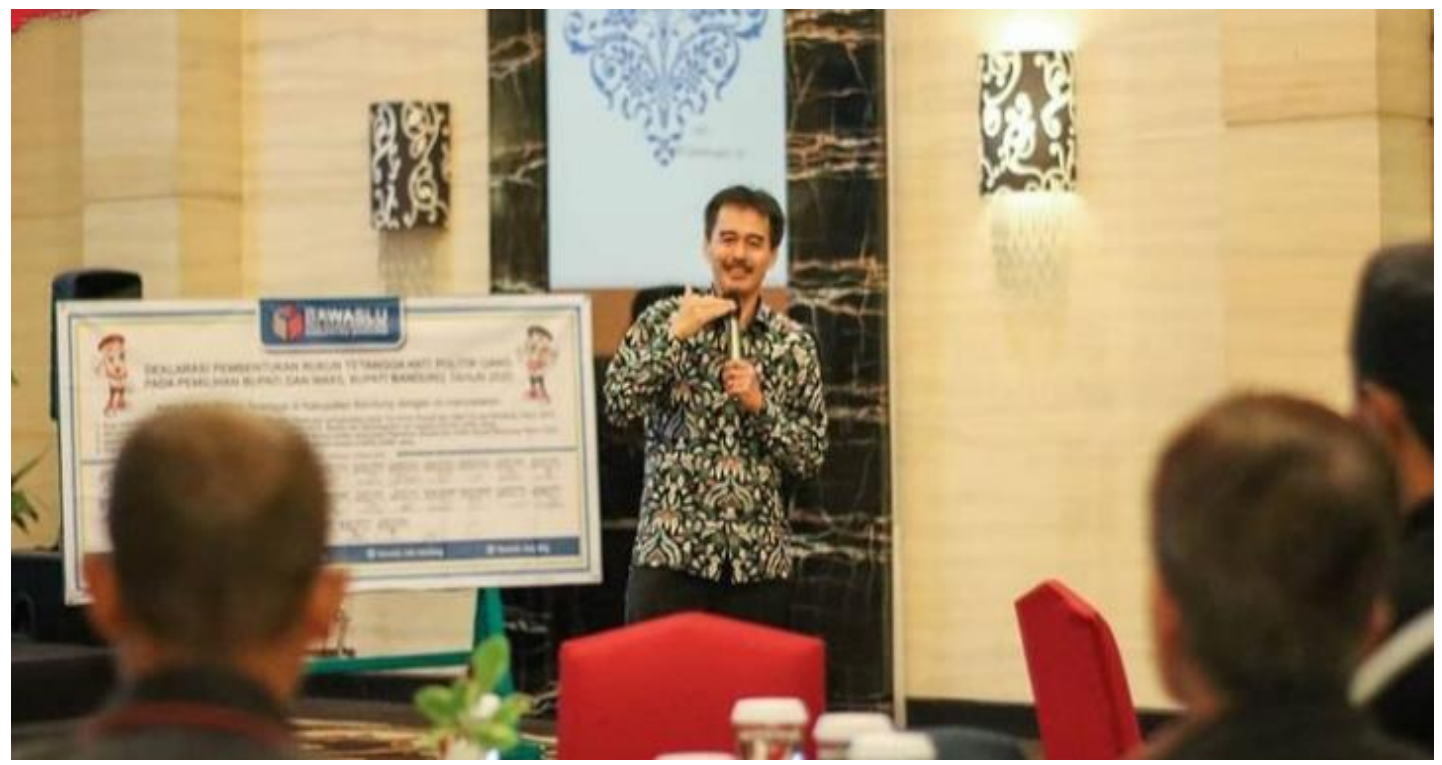

\section{Gambar 1: Pemberian Materi kepada Para Peserta}

Kegiatan berlangsung pada Kamis 12 Maret 2020 di Sutan Raja Hotel Sisingamangaraja Jl. Raya Soreang KM 17 no. 10 Cingcin Pamekaran Kecamatan Soreang Kabupaten Bandung, serta kemudian Surat Tugas Direktur LPPM Nomor 84/ST-PM/LPPM/USB YPKP/III/2020 tanggal 11 Maret 2020. Peserta kegiatan terdiri dari 60 orang perwakilan pengurus Rukun Tetangga di Kabupaten Bandung.
Teknik kegiatan berupa ceramah tentang arti penting pilkada, arti penting pengawasan dan partisipasi masyarakat, serta arti penting kesadaran dan gerakan masyarakat tentang antipolitik uang. Selain itu dilakukan diskusi interaktif dan bedah kasus berkenaan dengan berbagai fenomena dan peristiwa dalam rangkaian penyelenggaraan pilkada yang terjadi berdasarkan pengalaman beberapa kali pilkada sebelumnya.

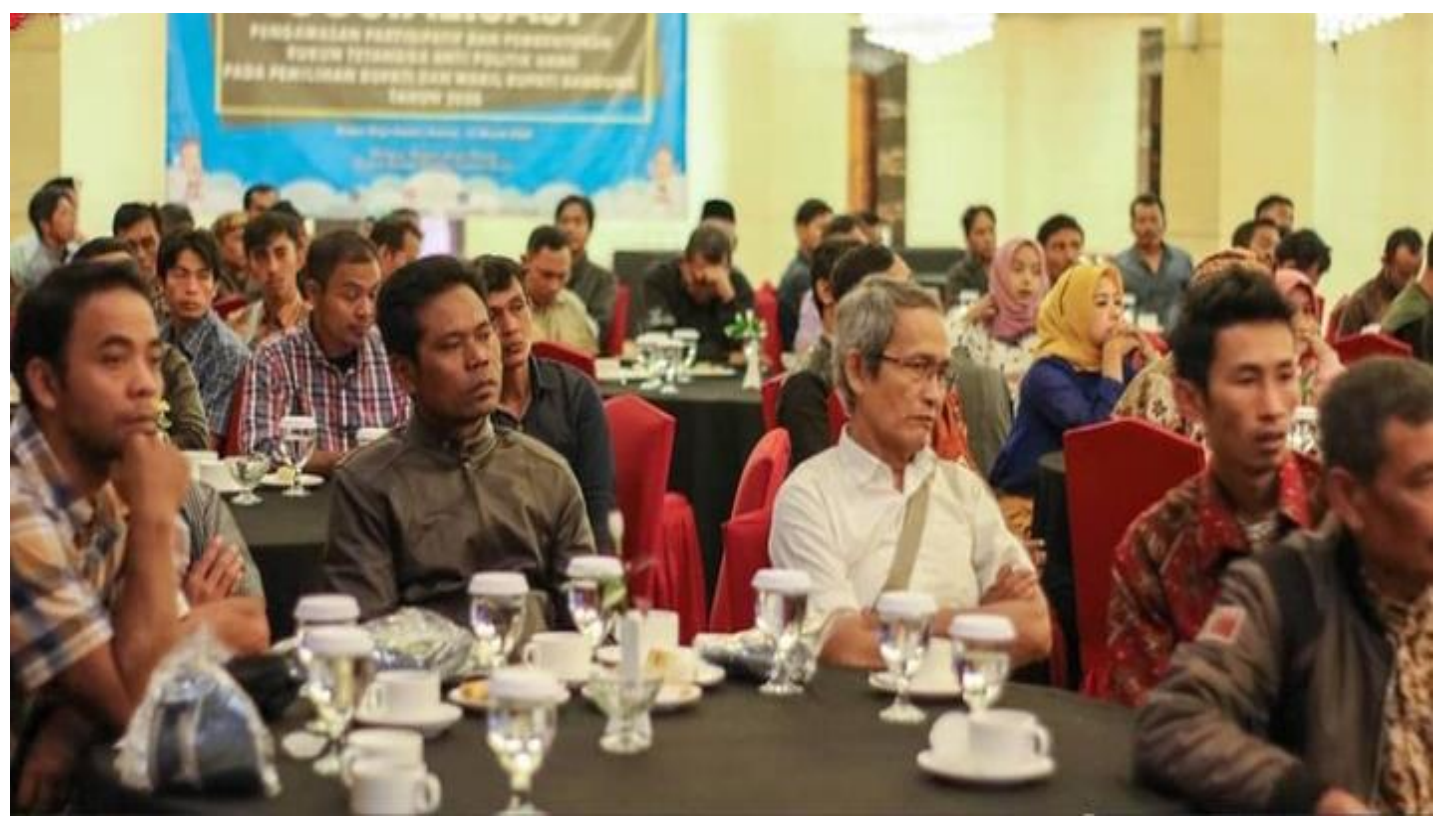




\section{Gambar 2: Peserta Sosialisasi}

HASIL DAN PEMBAHASAN

\section{Peran Pengawasan Pilkada}

Peran penting pengawasan sebagai salah satu aspek penyelenggaraan pilkada tidak terlepas dari terbitnya berbagai kebijakan negara yang mengatur mengenai pemilu dan pilkada. Dalam kerangka ini lahirnya Undang-Undang Nomor 7 Tahun 2017 tentang Pemilu [2] dan UndangUndang Nomor 1 Tahun 2015 tentang Penetapan Perpu Nomor 1 Tahun 2014 tentang Pemilihan Gubernur, Bupati dan Walikota menjadi Undang-Undang (yang telah mengalami dua kali perubahan) [3] menjadi bagian penting dari upaya peningkatan kualitas demokrasi dan kehidupan politik secara lebih luas di tingkat lokal.

Bawaslu sesuai dengan Pasal 1 angka 17 Undang-Undang Nomor 7 Tahun 2017 yang bertugas mengawasi penyelenggaraan pemilu, beserta seluruh jajarannya sampai ke tingkat yang paling bawah memiliki peran strategis untuk turut mewujudkan harapan tersebut [2]. Salah satu penopang keberadaan pengawasan pemilu termasuk pilkada ini adalah Badan Pengawas Pemilu tingkat kabupaten khususnya di Kabupaten Bandung. Adanya delapan daerah kabupaten/kota di Provinsi Jawa Barat yang menyelenggarakan pilkada serentak pada tahun 2020, termasuk Kabupaten Bandung merupakan tantangan besar untuk memastikan dapat berjalannya perhelatan demokrasi di tingkat lokal ini secara lebih berkualitas.

Dalam siklus manajemen telah dipahami bersama bahwa pengawasan merupakan salah satu fungsi organik administrasi/manajemen yang sangat menentukan ketercapaian tujuan organisasi yang telah ditetapkan. Fungsi pengawasan ini dilaksanakan untuk memastikan bahwa pelaksanaan aktivitas organisasi sesuai dengan standar, kebijakan, rencana atau program yang telah ditetapkan. Dalam rangka ini, tugas dan wewenang Bawaslu Kabupaten/Kota sebagaimana diatur dalam Pasal 30 dalam mengawasi tahapan penyelenggaraan pilkada benar-benar sangat signifikan sebagai bagian dari upaya mewujudkan pilkada berkualitas. Berbagai program penyelenggaraan pilkada sesuai tahapan yang telah ditetapkan KPU setempat menjadi acuan Bawaslu untuk melakukan pengawasan.

Mengingat arti penting pengawasan penyelenggaraan pilkada serta demikian sangat luasnya area tugas dan wewenang Bawaslu, maka sangat diperlukan adanya partisipasi masyarakat untuk mendukung hal tersebut. Dengan luas wilayah Kabupaten Bandung yang terdiri dari 31 kecamatan, 270 desa dan 10 kelurahan, tentu merupakan tantangan tersendiri untuk memaksimalkan peran pengawasannya.

Partisipasi berbagai elemen masyarakat merupakan kebutuhan mutlak. Hal ini karena tidak mungkin semua beban penyelenggaraan pemerintahan dan pembangunan, termasuk di dalamnya pembangunan politik berupa penyelenggaraan pilkada, dapat sepenuhnya dibebankan kepada lembaga pengawasan pilkada. Dengan kata lain, dapat dikatakan bahwa salah satu syarat bagi keberhasilan 
penyelenggaraan pilkada adalah adanya partisipasi masyarakat dalam pelaksanaan pilkada.

Dalam rangka ini tampak bahwa para peserta sosialisasi memahami benar arti penting fungsi pengawasan untuk berjalannya pilkada sesuai dengan ketentuan. Hal ini tergambarkan pada sesi dialog interaktif yang melibatkan beberapa peserta sosialisasi.

\section{Gerakan Masyarakat Antipolitik Uang}

Salah satu aspek penting dalam pelaksanaan pengawasan pilkada adalah laporan masyarakat terhadap dugaan pelanggaran regulasi pilkada, baik yang dilakukan oleh aparat penyelenggara, peserta pilkada, aparat negara, maupun warga masyarakat ada umumnya. Salah satu jenis permasalahan yang selalu muncul dalam penyelenggaraan pilkada adalah politik uang, yang baik dalam jangka pendek maupun jangka panjang akan sangat merusak sendi-sendi kehidupan berdemokrasi pada tingkat daerah. Padahal perangkat regulasi yang mengatur hal tersebut telah sangat eksplisit dalam setiap perhelatan pilkada diatur dalam setiap regulasi pilkada.

Fakta masih menunjukkan bahwa dari waktu ke waktu politik uang masih menjadi noda dalam penyelenggaraan pilkada di berbagai daerah. Secara sosiopsikologis, hal yang membahayakan kultur dan kehidupan demokrasi dalam jangka panjang adalah ketika warga masyarakat yang menyaksikan adanya politik uang justru menganggap hal tersebut sebagai sesuatu yang lumrah dilakukan. Sikap dan perilaku warga masyarakat yang permisif seperti ini benar-benar harus dihentikan apabila semua pemangku kepentingan pilkada masih menginginkan terwujudnya pilkada yang makin berkualitas.

Salah satu aspek yang dapat ditekankan pada warga masyarakat adalah tentang asal usul dana yang digunakan sebagai politik uang, serta konsekuensi apabila kandidat kepala daerah yang bersangkutan memenangi pilkada. Sangat mungkin terjadi dana berasal dari cukong yang sejak awal berkalkulasi akan kemenangan kandidat yang didukungnya.

Akhirnya korupsi kebijakan akan terjadi ketika sang kandidat terpilih sebagai kepala daerah, dan hal itu merupakan cikal bakal tersedotnya anggaran publik untuk kepentingan pribadinya untuk balas jasa selama pilkada berlangsung. Guna melawan politik uang secara masif tentu harus ada kesadaran kolektif bahwa sebenarnya rakyat adalah pihak yang paling dirugikan oleh skema praktek politik uang [4].

Apabila hal ini dibiarkan, maka lama kelamaan sangat mungkin praktik yang menodai perhelatan demokrasi ini akan dianggap sebagai suatu kebiasaan yang wajar dan normal. Suatu ketika, boleh jadi warga masyarakat tidak lagi merasa bersalah atau berdosa ketika melibatkan diri atau terlibat dalam praktik ini. Tentu akan makin berat tugas Bawaslu dan jajarannya sampai ke tingkat paling bawah untuk memastikan berjalannya pilkada sesuai dengan koridor peraturan perundang-undangan.

Oleh karenanya tumbuhnya kesadaran individual tentang bahaya politik uang dari tiap 
warga masyarakat secara akumulatif akan menjadi gerakan bottom up untuk perang melawan politik uang. Para peserta sosialisasi tampaknya sepakat bahwa dorongan dan gerakan dari bawah ini, berupa ketokohan para pengurus Rukun Tetangga sangat penting bagi tumbuhnya kesadaran kolektif untuk menolak segala macam bentuk politik uang.

\section{Peran Rukun Tetangga}

Sesuai dengan ketentuan Pasal 1 Peraturan Bupati Bandung Nomor 67 Tahun 2011 tentang Rukun Tetangga dan Rukun Warga [5], maka setiap Rukun Tetangga (RT) sebagai lembaga kemasyarakatan yang menjadi mitra pemerintah daerah di level paling bawah benarbenar sangat besar dan menentukan bagi terwujudnya pilkada yang terbebas dari politik uang. Hal ini antara lain karena pada umumnya yang menjadi pengurus RT di setiap daerah adalah para tokoh masyarakat, para opinion leader, dan para penggerak warga masyarakat yang sangat efektif dalam membantu tiap program pemerintah.

Gerakan antipolitik uang yang bermula dari dan didukung oleh setiap RT secara simultan sinergis berkesesuaian dengan tugas Bawaslu. Bawaslu kabupaten/kota dalam Pasal 101 Undang-Undang Nomor 7 Tahun 2017 antara lain bertugas mencegah terjadinya praktik politik uang [2]. Dalam konteks ini, Bawaslu bertugas antara lain sebagaimana diatur dalam Pasal 102 yaitu meningkatkan partisipasi dalam pengawasan pemilu, termasuk penyelenggaraan pilkada.
Oleh karena itu, pencanangan gerakan masyarakat antipolitik uang yang melibatkan pengurus RT di seluruh wilayah kerja Bawaslu benar-benar akan berkontribusi terhadap kualitas penyelenggaraan pilkada secara umum. Sebagai misal, Pasal 33 Peraturan Bawaslu Nomor 10 Tahun 2017 tentang Pengawasan Tahapan Pencalonan Pemilihan Gubernur dan Wakil Gubernur, Bupati dan Wakil Bupati serta Walikota dan Wakil Walikota [6], telah mengamanatkan agar pengawas pilkada melibatkan partisipasi pihak terkait yang dilakukan antara lain dengan kerjasama dengan kelompok masyarakat.

Para peserta sosialisasi tampaknya meyakini peran penting keberadaannya sebagai unsur lembaga kemasyarakatan yang dapat menjadi ujung tombak bagi gerakan masyarakat antipolitik uang ini.

\section{KESIMPULAN DAN SARAN}

Kebijakan atau program untuk terselenggaranya pilkada yang berkualitas telah digulirkan atas nama kepentingan publik, yang belum tentu akan selalu mulus dalam implementasinya. Pilkada yang berkualitas dengan makin rendahnya kasus politik uang menjadi tantanagan bagi Bawaslu dan para pemangku kepentingan pilkada lainnya. Oleh karena itu, pengawasan partisipatif yang melibatkan seluruh komponen masyarakat, khususnya pengurus RT menjadi sangat penting. Keyakinan, optimisme, kesungguhan dan kesinambungan gerakan antipolitik uang, perlu terus digalakkan. Hanya dengan cara ini, penyelenggaraan pilkada di masa depan akan 
P-ISSN: 2745-5912

E-ISSN: 2745-9047

makin berkualitas. Bawaslu perlu secara berkesinambungan terus menumbuhkan dan mengembangkan kesadaran masyarakat melalui pengurus Rukun Tetangga tentang bahaya politik uang bagi perkembangan demokrasi dan pemerintahan.

\section{DAFTAR PUSTAKA}

[1] Undang-Undang Nomor 12 Tahun 2012 tentang Pendidikan Tinggi.

[2] Undang-Undang Nomor 7 Tahun 2017 tentang Pemilu.

[3] Undang-Undang Nomor 1 Tahun 2015 tentang Penetapan Perpu Nomor 1 Tahun
2014 tentang Pemilihan Gubernur, Bupati dan Walikota menjadi Undang-Undang.

[4] C. Sutrisno, "Partisipasi Warga Negara dalam Pilkada," vol. 2, no. 2, 2017.

[5] Peraturan Bupati Bandung Nomor 67 Tahun 2011 tentang Rukun Tetangga dan Rukun Warga.

[6] Peraturan Bawaslu Nomor 10 Tahun 2017 tentang Pengawasan Tahapan Pencalonan Pemilihan Gubernur dan Wakil Gubernur, Bupati dan Wakil Bupati serta Walikota dan Wakil Walikota. 